\title{
Slitine s prisjetljivosti oblika (II. dio): podjela, proizvodnja i primjena
}

\author{
I. Ivanić, ${ }^{*}$ M. Gojić i S. Kožuh
}

Metalurški fakultet, Sveučilište u Zagrebu, Aleja narodnih heroja 3, 44103 Sisak, Hrvatska

\begin{abstract}
Slitine s prisjetljivosti oblika funkcionalni su "pametni" materijali s jedinstvenim svojstvom prisjetljivosti oblika. Prisjetljivost oblika karakteristična je sposobnost materijala koja je posljedica martenzitne fazne transformacije, a karakterizira je vraćanje slitine u oblik koji je imala prije deformacije. U radu su detaljno objašnjene slitine s prisjetljivosti oblika s gledišta njihove podjele, proizvodnje i primjene. $U$ industrijskoj primjeni najčešće se upotrebljavaju slitine na bazi nikla i titanija, te slitine na bazi bakra. Slitine na bazi željeza i plemenitih metala još uvijek nemaju značajniju industrijsku primjenu. Slitine s prisjetljivosti oblika uglavnom se proizvode postupcima indukcijskog taljenja, brzog očvršćivanja (primjerice melt spinning) i kontinuiranog lijevanja.
\end{abstract}

Ključne riječi: "Pametni" materijali, NiTi, Cu-slitine, brzo očvršćivanje

\section{Uvod}

Termin slitine s prisjetljivosti oblika (SMA) primjenjuje se na skupinu metalnih materijala koji pri određenom postupku toplinske obrade pokazuju sposobnost vraćanja u njihovo prethodno definirano stanje ili oblik. Navedeni materijali mogu se plastično deformirati na relativno niskim temperaturama te se nakon izloženosti višim temperaturama vraćaju u oblik prije deformacije. Promjena oblika posljedica je austenitno-martenzitne transformacije u strukturi slitine. Austenitno-martenzitna transformacija okarakterizirana je temperaturama početka i završetka austenitne transformacije $\left(A_{\mathrm{s}} \mathrm{i} A_{\mathrm{f}}\right)$ te temperaturama početka i završetka martenzitne transformacije $\left(M_{\mathrm{s}}\right.$ i $\left.M_{\mathrm{f}}\right)$.

Efekt prisjetljivosti oblika uočio je švedski istraživač Ölander 1932. godine, na slitini zlata i kadmija, kod koje se pokazalo da martenzitna faza može poprimiti oblik koji se s promjenom temperature mijenja. Veća pažnja počela se posvećivati ovoj pojavi kada su Buehler i suradnici otkrili efekt prisjetljivosti oblika u slitini nikla i titanija. ${ }^{1-7}$

Nedugo nakon toga dolazi do većeg zanimanja za istraživanja navedenih slitina. Postoji velik broj slitina koje posjeduju prisjetljivost oblika:

- slitine na bazi nikla: NiTi (tzv. nitinol), NiMnGa

- slitine na bazi bakra: Cu-Zn-X (X = Al, Si, Sn, Ga, Mn), Cu-Al-X (X = Ni, Be, Zn, Mn), Cu-Zn-Al-X (X = Ni, Mn)

- slitine na bazi željeza: Fe-Mn, FePt, FeMnSi, FeCoNiTi itd. - slitine na bazi plemenitih metala: AuCd, AuAg, PtAI, PtTi, PtGa

- tzv. "egzotične" slitine: InTe, InCd, VNb. ${ }^{8}$

Slitina NiTi, kao najpoznatija slitina s prisjetljivosti oblika, ima široku primjenu u strojarskoj industriji, elektroničkoj in-

\footnotetext{
*Autor za dopisivanje: Ivana Ivanić, mag. ing. met.
}

e-pošta: iivanic@simet.hr dustriji, astronautičkoj industriji i medicini zbog povoljnih termomehaničkih i termoelektričnih svojstava te biokompatibilnosti. $2,9,10$

Slitine na bazi bakra komercijalno su privlačne za primjenu ponajprije kao zamjena za skupe slitine NiTi u nemedicinskim uvjetima primjene. ${ }^{11}$ Međutim ograničavajući faktori za industrijsku primjenu slitine s prisjetljivosti oblika na bazi bakra su niska toplinska stabilnost, krhkost i nezadovoljavajuća čvrstoća. ${ }^{12}$

Osnovna prednost slitina CuAINi pred ostalim slitinama s prisjetljivosti oblika je niska cijena te mogućnost primjene na višim temperaturama (do $200{ }^{\circ} \mathrm{C}$ ). S druge strane, njena praktična primjena je ograničena zbog teške obradljivosti i sklonosti krhkom lomu na granici zrna. ${ }^{12-17}$ Međutim postoji niz prednosti slitine CuAINi u odnosu na slitinu NiTi s prisjetljivosti oblika: lakše taljenje, lijevanje i kontrola kemijskog sastava, veći Youngov modul elastičnost, viša radna temperatura i, što je najvažnije, veća stabilnost dvosmjernog efekta prisjetljivosti oblika. 9,13,18 $^{2}$

Cilj rada je pregledno prikazati najčešće upotrebljavane slitine s prisjetljivosti oblika, postupke proizvodnje te svojstva i primjenu navedenih materijala.

\section{Slitine s prisjetljivosti oblika}

\section{Slitina NiTi (nitinol)}

Šezdesetih godina 20. stoljeća Buechler i suradnici otkrili su efekt prisjetljivosti oblika na slitini nikal-titanij (NiTi) u laboratoriju (Naval Ordnance Laboratory) prema kojem je slitina dobila ime NiTiNOL. ${ }^{1,2,4,5}$ Najpoznatija slitina NiTi je $\mathrm{Ni}_{50} \mathrm{Ti}_{50} \cdot{ }^{6}$ Temperature faznih transformacija slitine NiTi značajno ovise o kemijskom sastavu, pogotovo sadržaju nikla u slitini, te uglavnom iznose od $-40{ }^{\circ} \mathrm{C}$ do $+100{ }^{\circ} \mathrm{C} .{ }^{16}$

Fazni dijagrami su vrlo važni za razumijevanje mikrostrukture slitina s prisjetljivosti oblika. Pomoću faznog dijagrama 
moguće je odrediti stabilnost određenih faza. Slika 1 predstavlja fazni dijagram slitine NiTi s prisjetljivosti oblika. Visokotemperaturna austenitna faza ima kubičnu strukturu B2. Faza TiNi s tipom strukture B2 nastaje sporim hlađenjem na sobnu temperaturu. $U$ faznom dijagramu značajan je središnji dio između faza $\mathrm{Ti}_{2} \mathrm{Ni}$ i $\mathrm{TiNi}_{3}$. Faza $\mathrm{Ti}_{2} \mathrm{Ni}$ je kubične strukure, dok faza $\mathrm{TiNi}_{3}$ ima heksagonsku strukturu $\mathrm{DO}_{24}$. Brzim hlađenjem slitina se transformira u martenzit. Niskotemperaturna martenzitna faza je monoklinske strukture B19'. Fazni dijagram još uvijek je predmet brojnih rasprava zbog prisutnosti ili odsutnosti eutektoidnog raspada $\mathrm{TiNi} \rightarrow$ $\mathrm{Ti}_{2} \mathrm{Ni}_{3} \rightarrow \mathrm{TiNi}_{3}$ na temperaturi $630{ }^{\circ} \mathrm{C} .6,7,19$

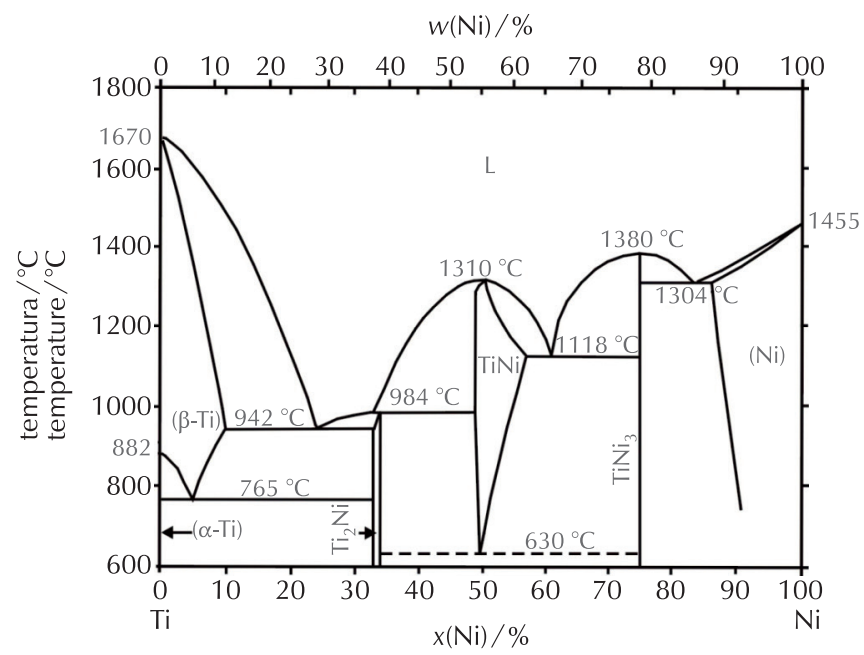

S I i k a 1 - Fazni dijagram slitine NiTi s prisjetljivosti oblika ${ }^{6}$ Fig. 1 - Phase diagram of NiTi shape memory alloy ${ }^{6}$

Važna činjenica za slitinu NiTi je i povoljan Youngov modul elastičnosti koji je znatno veći od Youngova modula ljudske kosti, međutim manji od mnogih ostalih slitina. ${ }^{20} \mathrm{Na}$ slici 2 je shematski prikazana usporedba krivulja naprezanje - deformacija za nehrđajući čelik, slitine NiTi i kost. Iz slike 2 se vidi da je vrlo slično ponašanje slitine NiTi i kosti. ${ }^{21}$

Oporavak istezanja nakon deformacije polikristalne slitine $\mathrm{NiTi}$ je do $8 \%$ za jednosmjerni efekt prisjetljivosti oblika, dok za dvosmjerni efekt iznosi $4 \%{ }^{22}$ Da bi slitina postigla svojstva efekta prisjetljivosti oblika, u posljednjem postupku procesa izrade mora se hladno obrađivati, nakon čega slijedi pravilan postupak toplinske obrade. ${ }^{16}$

Proizvodnja slitine NiTi iznimno je zahtjevna ponajprije zbog oksidacije titanija, loše obradljivosti slitine i skupih sirovina. ${ }^{23}$ Isto tako, s obzirom na značajan udjel nikla u slitini, ioni nikla nepovoljno utječu na biokompatibilnost slitine zbog visokog alergenskog i karcinogenog djelovanja na ljudski organizam. Stoga, iznimno bitno svojstvo slitine NiTi s prisjetljivosti oblika je korozijska otpornost, ponajprije u slučaju implantacije u ljudski organizam. Slitine NiTi su relativno stabilne, kontinuirano i visoko pokrivene zaštitnim oksidnim slojem koji se sastoji od $\mathrm{TiO}_{2}$ na vanjskoj površini, što sprječava koroziju slitine. Nastanak filma $\mathrm{TiO}_{2}$ spontan je pri izlaganju slitine zraku i/ili vlagi, jer je titanij jako reaktivan i ima velik afinitet prema kisiku. Međutim pasivni film na slitini nije potpuno stabilan u uvjetima u kojima se primjenjuje. Ugradbom materijala u tijelo, elektrokemijske reakcije mogu dovesti do nastanka produkata koji mogu biti toksični za okolno tkivo. Korozija metalnih materijala u ljudskom tijelu uzrokuje otpuštanje metalnih iona dulje vrijeme te se korozijski produkti mogu kombinirati s proteinima i enzimima. Ljudsko tkivo sadrži vodu, otopljeni kisik, proteine i razne ione kao i kloride i hidrokside, koji svakako predstavljaju agresivno okruženje za materijale koji se upotrebljavaju kao implantati. ${ }^{19,24}$

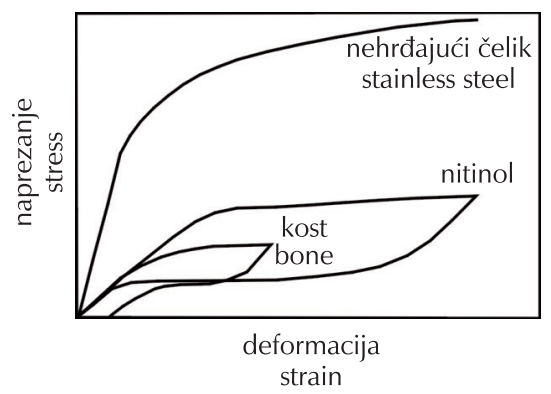

S I i k a 2 - Shematski prikaz krivulje naprezanje - deformacija za nehrđajući čelik, NiTi i kost ${ }^{21}$

F ig. 2 - Schematic illustration stress - strain curves of stainless steel, NiTi and bone ${ }^{21}$

Kako bi se što bolje kontrolirala mogućnost otpuštanja iona nikla koji su potencijalno štetni za ljudsko tkivo, razvijeno je nekoliko metoda modifikacije površine.$^{20}$ Osim ostalog to su: površinske prevlake, ionska implantacija, plazmatska implantacija, CVD (chemical vapor deposition, kemijsko taloženje iz parne faze), itd. koje su utjecale na poboljšanje biokompatibilnosti. ${ }^{25}$

Dodatak legirajućih elemenata, primjerice željeza, sprječava nastajanje R-faze, koja prethodi martenzitnoj faznoj transformaciji kod slitine NiTi i koju karakterizira brz porast električne otpornosti i toplinske promjene. Dodatkom niobija u vrlo malim količinama odgađa se povratna fazna transformacija i efekt prisjetljivosti oblika na više temperature. Također, zamjenom sadržaja nikla s paladijem (oko $20 \%$ ) dobiva se slitina pogodna za visokotemperaturnu primjenu $\left(200-300{ }^{\circ} \mathrm{C}\right) .{ }^{16}$

Nitinol kao najpoznatija slitina s prisjetljivosti oblika posjeduje superiorna termomehanička i termoelektrična svojstva i najčešće je upotrebljavana slitina s prisjetljivosti oblika. Posebno je značajna zbog svojih dobrih mehaničkih svojstava i biokompatibilnosti. Stoga joj je i najčešća primjena biomedicinskog karaktera (implantati). 20,23,26

\section{Slitine s prisjetljivosti oblika na bazi bakra}

Slitine s prisjetljivosti oblika na bazi bakra karakterizira visokotemperaturno stabilna $\beta$-faza, s povišenim temperaturama martenzitne fazne transformacije (ponajprije temperature početka nastanka martenzita, $M_{\mathrm{s}}$ ) iznad $100{ }^{\circ} \mathrm{C}$. Temperatura $M_{\mathrm{s}}$ ima tendenciju porasta $\mathrm{s}$ porastom sadržaja aluminija. Dodatak male količine srebra slitini Cu-Al povećava tvrdoću slitine i poboljšava otpornost na naponsku koroziju. Malim dodatkom berilija u slitinu CuAl blizu eutektoidnog sastava dolazi do stabilizacije $\beta$-faze i snižavanja $M_{s^{\prime}}$ dok se sama priroda martenzitne transformacije ne mijenja. Slitine s dodatkom berilija korisne su za primjenu u seizmički otpornim konstrukcijama zbog sposobnosti razvijanja velikog 
nelinearnog oporavka istezanja pri mehaničkom opterećenju i rasterećenju što je povezano s nastankom naprezanjem induciranog martenzita. ${ }^{27,28}$ Komercijalno dostupne slitine $\mathrm{s}$ prisjetljivosti oblika na bazi bakra su CuZnAl i CuAINi te njihove četverokomponentne inačice. ${ }^{1,29,30}$

\section{Slitine CuZnAl s prisjetljivosti oblika}

Slitina CuZnAl je druga komercijalno primijenjena slitina s prisjetljivosti oblika, odmah nakon NiTi. U usporedbi sa slitinom NiTi, slitina CuAIZn je jednostavnija i jeftinija za proizvodnju, ima bolju električnu i toplinsku provodnost te veću duktilnost. Međutim slitina CuZnAl ima znatno inferiornija svojstva prisjetljivosti oblika. ${ }^{31}$

Slitine CuZnAl s prisjetljivosti oblika pokazuju značajan efekt prisjetljivosti oblika u određenom području kemijskog sastava. Slitina ima $\beta$-faznu prostorno centriranu kubičnu strukturu, bcc, koja je stabilna na visokim temperaturama. Uobičajeni postupak je da se slitina toplinski obrađuje (betatizacija) kako bi se zadržala $\beta$-faza. Nakon betatizacije slijedi hlađenje u vodi kako bi se $\beta$-faza transformirala u martenzit. ${ }^{32}$ Slitine CuZnAl imaju vrlo veliku tendenciju raspada na ravnotežne faze tijekom pregrijavanja pa je potrebna stabilizacija martenzita.

Slika 3 prikazuje ravnotežni fazni dijagram slitine CuZnAl pri vertikalnom presjeku pri $w(\mathrm{Al})=6 \%$. Visokotemperaturna $\beta$-faza je neuređene strukture bcc. Nakon brzog hlađenja na sobnu temperaturu nastaje složena struktura $\mathrm{B} 2{\mathrm{i} \mathrm{DO}_{3}}$ (ili L2 1 ) koja se zatim transformira u martenzit 9R (6M) ili 18R (6M) daljnjim hlađenjem ili bez njega, ovisno o sastavu slitine. Povećanjem sadržaja aluminija $\beta$-faza je podložna raspadu na $\alpha$-fazu (primarnu čvrstu otopinu $C u, f c c)$ i $\gamma$-fazu $\left(\mathrm{Cu}_{5} \mathrm{Zn}_{8}\right.$, kubična struktura) pri $427{ }^{\circ} \mathrm{C} .{ }^{6,7,19}$

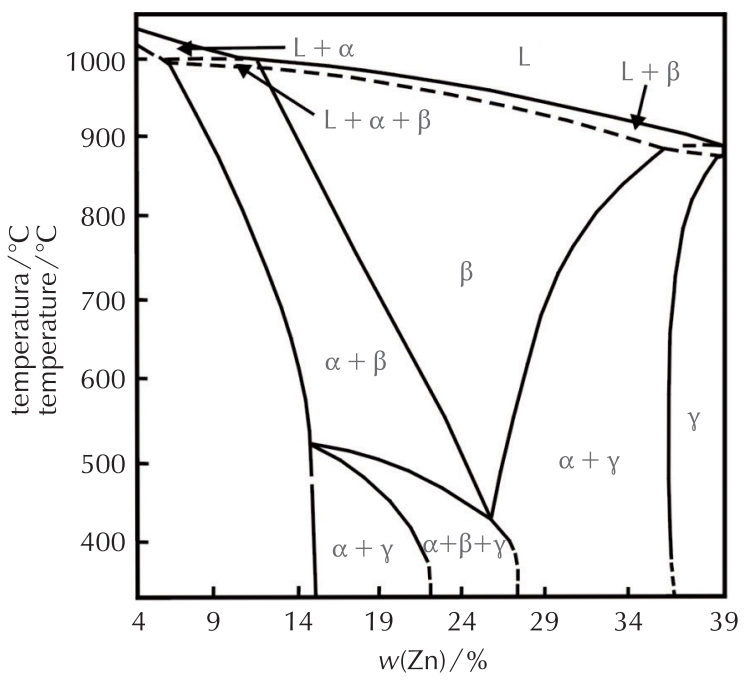

S I i k a 3 - Ternarni dijagram CuZnAl slitine - vertikalni presjek kod 6 mas. \% Al ${ }^{6}$

F i g . 3 - Ternary diagram of CuZnAl alloy - vertical cross-section at 6 wt. $\% \mathrm{Al}^{6}$

Prisutnost dodataka poput kobalta, cirkonija, bora ili titanija nužna je za dobivanje zrna od 50 do $100 \mu \mathrm{m}$. Bor se dodaje kako bi se poboljšala duktilnost slitine s prisjetljivosti oblika. ${ }^{33}$

\section{CuAlNi slitine s prisjetljivosti oblika}

Slitine CuAINi upotrebljavaju se zbog niže cijene i lakše proizvodnje u odnosu na slitinu NiTi. ${ }^{34}$ Taljenje se najčešće provodi u vakuumskim indukcijskim pećima uz zaštitnu atmosferu inertnog plina, kako bi se spriječila oksidacija aluminija, dok se postupci metalurgije praha i tehnologije brzog očvršćivanja primjenjuju za proizvodnju sitnozrnatih slitina bez upotrebe elemenata koji služe za usitnjavanje zrna. ${ }^{1,35,36}$

Polikristalne slitine CuAINi proizvedene konvencionalnim putem vrlo su krhke, što je povezano s velikom elastičnom anizotropijom i krupnozrnatom mikrostrukturom. Anizotropija martenzitne transformacije ima izravne posljedice na makroskopsko ponašanje polikristala. Polikristali imaju nizak stupanj oporavka oblika zbog nasumično distribuirane orijentacije te je pseudoelastični efekt ograničen na $2 \%$, što je premala vrijednost za praktičnu upotrebu. ${ }^{37}$

Bolja kontrola kemijskog sastava i sitnozrnata mikrostruktura nakon lijevanja mogu se dobiti proizvodnjom slitina postupcima brzog očvršćivanja te metalurgijom praha i procesima mehaničkog legiranja. Međutim navedene metode još uvijek nemaju sustavne i pogodne uvjete proizvodnje za dobivanje zadovoljavajućeg efekta prisjetljivosti oblika. ${ }^{35,38}$

Temperatura $M_{\mathrm{s}}$ slitina s prisjetljivosti oblika iznimno je ovisna o kemijskom sastavu. Međutim isto tako i svojstva poput pseudoelastičnosti i efekta prisjetljivosti oblika ovise o kemijskom sastavu. Stoga se navedena svojstva i temperature faznih transformacija mogu prilagođavati promjenom kemijskog sastava. S obzirom na to da slitine na bazi bakra imaju veliko zrno, dodaju se određeni elementi poput titanija, bora, cirkonija kako bi spriječili rast zrna. Za slitinu CuAINi najčešći je mikrolegirajući element titanij, koji stvara precipitate $\chi$-faze $\left((\mathrm{Cu}, \mathrm{Ni})_{2} \mathrm{TiAl}\right)$ koji sprječavaju porast zrna. ${ }^{1,29,30}$ Mangan se kao legirajući element dodaje zbog povećanja duktilnosti slitina CuAINi, te je odgovoran za nastanak $\beta$-faznog područja i poboljšanje termomehaničkih svojstva slitina s prisjetljivosti oblika. ${ }^{1,16,35}$

Praktična primjena slitina CuAINi ograničena je zbog slabe obradivosti i krhkosti (intergranularni lom). Visoka elastična anizotropija i precipitacija krhke $\gamma_{2}$-faze $\left(\mathrm{Cu}_{9} \mathrm{Al}_{4}\right)$ proizlazi iz hipereutektoidnog sastava slitine i povećanja zrna kada je slitina otapajuće žarena na visokim temperaturama u $\beta$-faznom području. Rezultat je žarenja smanjenje duktilnosti i obradivosti slitina. ${ }^{13,29}$ Područje $\beta$-faze uvelike ovisi o kemijskom sastavu slitine na što veliki utjecaj ima omjer broja elektrona i atoma $\left(N_{\mathrm{e}} / N_{\mathrm{a}}\right)$. $\beta$-fazno područje je najstabilnije kada je $N_{\mathrm{e}} / N_{\mathrm{a}}=1,48$. Kod slitina CuAINi omjer $N_{\mathrm{e}} / N_{\mathrm{a}}$ uvijek je $>1,48(3-5 \% \mathrm{Ni}, 11-14 \% \mathrm{Al})$, pa se precipitacija vrlo krhke $\gamma_{2}$-faze ne može izbjeći. ${ }^{16}$

Porast zrna i prisutnost krhke $\gamma_{2}$-faze $u$ polikristalnoj slitini CuAINi uzrokuje krhkost i povećava sklonost prema intergranularnom lomu tijekom obrade. Dodatak legirajućih elemenata, kao npr. mangana u udjelu $2 \%$, zamjenjujući dio aluminija, otežava eutektoidnu reakciju $\beta_{1} \rightarrow \alpha+\gamma_{2}$ uz održavanje potrebnih transformacijskih temperatura. Titanij u udjelu od $1 \%$ utječe na smanjenje veličine zrna i smanjuje intergranularni lom. ${ }^{39}$

Nikal u ternarnoj slitini omogućuje usporavanje difuzije bakra i aluminija, stoga tijekom hlađenja dolazi do zadrža- 
vanja jednofaznih uvjeta dok se ne dosegne temperatura $M_{\mathrm{s}}$. Povećanjem sadržaja nikla povećava se krhkost slitine i eutektoidna se točka pomiče prema većem udjelu aluminija. Povećavanjem sadržaja aluminija povećava se stabilnost martenzita, međutim snizuje se temperatura faznih transformacija. Stoga je optimalan sastav slitine s masenim udjelima $w(\mathrm{Cu})=11-14 \% \mathrm{i} w(\mathrm{Al})=3-4,5 .{ }^{16}$

Slitine CuAINi imaju bolju toplinsku stabilnost i više radne temperature od drugih slitina s prisjetljivosti oblika. ${ }^{29,35} \mathrm{Ka}$ rakteristične temperature martenzitnih transformacija su od -200 do $200{ }^{\circ} \mathrm{C}$ i ovise o udjelu aluminija i nikla, pri čemu je mnogo utjecajniji udjel aluminija. ${ }^{23,40}$

Pojava toplinski induciranog martenzita isključivo ovisi o kemijskom sastavu. Martenzit induciran naprezanjem, odnosno deformacijom, ovisi isključivo o kristalografskoj orijentaciji, ispitnoj temperaturi i tipu naprezanja. ${ }^{4}$ Proces stabilizacije svodi se na homogenizacijsko žarenje u $\beta$-faznom području i nužan je kako bi se inducirala reverzibilna martenzitna transformacija. ${ }^{40,42,43}$

Kod slitina CuAINi s prisjetljivosti oblika iz početne austenitne $\beta$-faze nastaju dva tipa toplinski induciranog martenzita $18 \mathrm{R}\left(\beta_{1}{ }^{\prime}\right)$ i $2 \mathrm{H}\left(\gamma_{1}{ }^{\prime}\right)$, što ovisi o kemijskom sastavu slitine, toplinskoj obradi i uvjetima naprezanja. Kod slitina s niskim sadržajem aluminija ( $w=11-13 \%$ ) hlađenjem nastaje martenzit 18R. Viši sadržaj aluminija ( $(>13 \%)$ prati formiranje martenzita $2 \mathrm{H}$. Ako je kemijski sastav takav da je na granici između nastanka obaju martenzita, tada oba mogu postojati u mikrostrukturi. S druge strane, ovi martenziti pokazuju različite transformacijske karakteristike..$^{40,44-49}$

Slika 4a prikazuje fazni dijagram slitine CuAINi pri vertikalnom presjeku kod $3 \% \mathrm{Ni}^{6,19,40}$ a na slici $4 \mathrm{~b}$ prikazan je fazni dijagram slitine CuAINi pri vertikalnom presjeku kod $14 \%$ Al. ${ }^{50}$ Faze koje se pojavljuju u dijagramima (slika 4a i 4b) i njihovo objašnjenje nalaze se u tablici 1 .

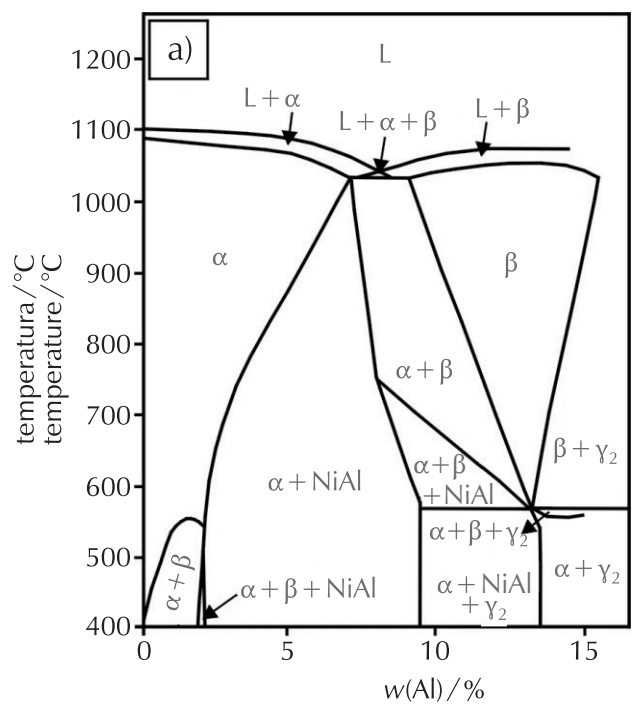

Ta bli c a 1 - Faze prisutne u ravnotežnim dijagramima slitine CuAlNi prikazanim na slici $4^{50}$

Ta ble 1 - Phases present in equilibrium diagrams of CuAINi alloys as shown in Fig. $4^{50}$

\begin{tabular}{|c|c|}
\hline $\begin{array}{l}\text { Faza } \\
\text { Phase }\end{array}$ & $\begin{array}{c}\text { Opis } \\
\text { Description }\end{array}$ \\
\hline$\alpha$ & $\begin{array}{l}\text { primarna čvrsta otopina } \mathrm{Al} \text { i } \mathrm{Ni} \text { u bakru, struktura fcc } \\
\text { primary solid solution of } \mathrm{Al} \text { and } \mathrm{Ni} \text { in cooper, fCC } \\
\text { crystal structure }\end{array}$ \\
\hline$\beta$ & $\begin{array}{l}\text { visokotemperaturna neuređena faza bazirana na } \\
\mathrm{Cu}_{3} \mathrm{Al} \text {, struktura bcc } \\
\text { high-temperature disordered phase based on } \\
\mathrm{Cu}_{3} \mathrm{Al} \text {, bcc crystal structure }\end{array}$ \\
\hline$\beta_{1}$ & $\begin{array}{l}\text { niskotemperaturna neuređena faza bazirana na } \\
\mathrm{Cu}_{3} \mathrm{Al} \text {, struktura } \mathrm{DO}_{3} \\
\text { low-temperature disordered phase based on } \mathrm{Cu}_{3} \mathrm{Al} \text {, } \\
\mathrm{DO}_{3} \text { structure }\end{array}$ \\
\hline$\gamma_{2}$ & $\begin{array}{l}\text { kompleksna faza } \mathrm{Cu}_{9} \mathrm{Al}_{4} \text {, kubična struktura } \\
\text { complex phase } \mathrm{Cu}_{9} \mathrm{Al}_{4} \text {, cubic crystal structure }\end{array}$ \\
\hline $\begin{array}{l}\text { martenzit } \\
\text { martensite }\end{array}$ & $\begin{array}{l}\text { uređena faza ortorombske strukture } \\
\text { ordered phase orthorhombic structure }\end{array}$ \\
\hline $\mathrm{NiAl}$ & $\begin{array}{l}\text { uređena faza, struktura bcc } \\
\text { ordered phase, bcc structure }\end{array}$ \\
\hline
\end{tabular}

U ravnotežnom stanju pri temperaturi $565{ }^{\circ} \mathrm{C}$ i $11,8 \%$ aluminija $\beta$-faza s prostorno centriranom kubičnom rešetkom (bcc) raspada se na $\alpha$-fazu (primarna čvrsta otopina aluminija i nikla u bakru, struktura fcc) i $\gamma_{2}$-fazu. Krhke faze kao što su $\gamma_{2}$-faza (kubična intermetalna faza $\mathrm{Cu}_{9} \mathrm{Al}_{4}$ ) i NiAl (struktura bcc) počinju precipitirati ispod eutektoidne temperature. Brzim hlađenjem iz $\beta$-faznog područja eutektoidni raspad je zaustavljen i odvija se martenzitna transformacija. ${ }^{19,40,44}$ Očvršćivanje kontinuirano lijevane slitine CuAINi, s $w(\mathrm{Cu})=13,16 \%$ i $w(\mathrm{Al})=4,11 \%$, prikazano je na slici 5 , gdje je vidljiva prisutnost sitnozrnate strukture uz rub štapa,

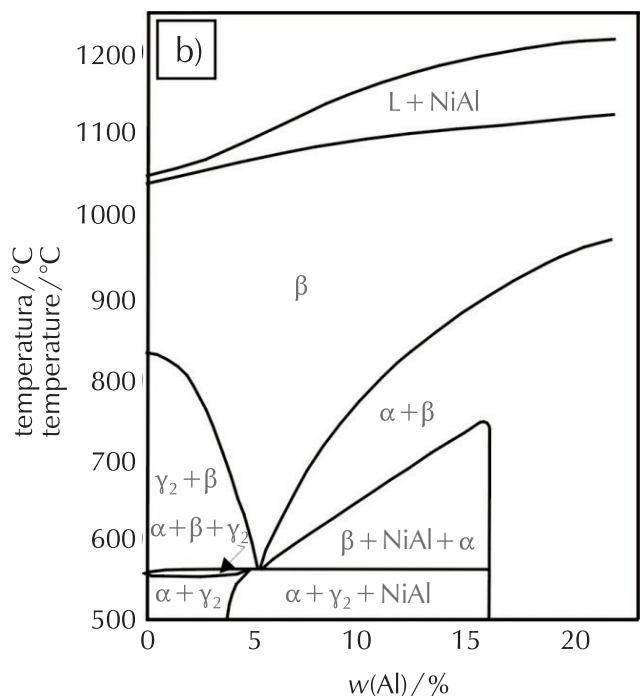

S I i k a 4 - Ternarni fazni dijagrami slitine CuAlNi vertikalni presjek pri $\mathrm{w}(\mathrm{Ni})=3 \%(\mathrm{a})^{6}$ i vertikalni presjek pri $\mathrm{w}(\mathrm{Al})=14 \%(b)^{50}$

$\mathrm{Fig} .4-$ Ternary phase diagrams of CuAlNi alloy vertical cross-section at $\mathrm{w}(\mathrm{Ni})=3 \%(\mathrm{a})^{6}$ and vertical cross-section at $\mathrm{w}(\mathrm{Al})=14 \%(\mathrm{~b})^{50}$ 

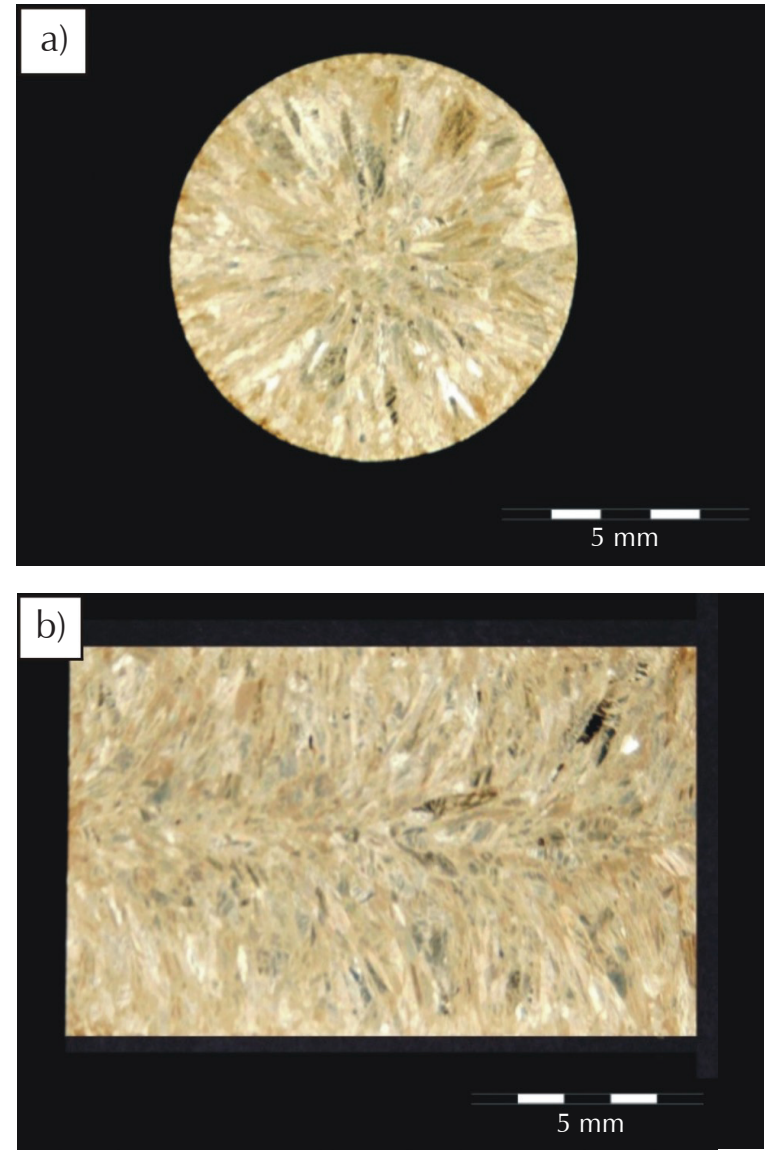

S I i k a 5 - Poprečni (a) i uzdužni (b) presjek štapa CuAlNi slitine nakon kontinuiranog lijevanja ${ }^{51}$

F i g . 5 - Lateral (a) and longitudinal (b) cross section of CuAlNi alloy bar after continuous casting ${ }^{51}$

stubičasta zrna kao posljedica usmjerenog očvršćivanja te istoosna zrna u središnjem dijelu štapa. Martenzitna mikrostruktura prikazana je na slikama 6a i 6b. Vidljivo je da se mikrostruktura sastoji od spontano nastalog martenzita igličastog oblika. Prosječna veličina zrna kontinuirano lijevane slitine CuAlNi s $w(\mathrm{Cu})=13,16 \%$ i $w(\mathrm{Al})=4,11 \%$ iznosila je $98,78 \mu \mathrm{m} .{ }^{51}$

Slitina CuAINi se teško plastično deformira kretanjem dislokacija. ${ }^{52}$ Zbog loše hladne obradljivosti na ovim slitinama provodi se međužarenje na temperaturama iznad $800{ }^{\circ} \mathrm{C}, \mathrm{tj}$. u $\beta$-faznom području. ${ }^{37,40}$

Efekt prisjetljivosti oblika u slitinama CuAINi podložan je starenju nakon kaljenja. ${ }^{9}$ Stoga je potrebno prilagoditi i stabilizirati temperaturu martenzitne transformacije, optimizirati toplinsku stabilnost i mehanička svojstva. ${ }^{53}$ Starenje nakon zakaljivanja potrebno je provoditi iznad temperature $A_{f}$, kako bi se utvrdile temperature faznih transformacija. Toplinska stabilnost slitina bakra s prisjetljivosti oblika ograničena je brzinom raspada martenzita, stoga treba izbjegavati duže držanje slitina na temperaturama iznad $150-200{ }^{\circ} \mathrm{C}$. Starenje na nižim temperaturama može pomaknuti temperature faznih transformacija. ${ }^{1}$ Gornja granica za transformaciju je 200 ${ }^{\circ} \mathrm{C}$, iznad koje slijedi nagla degradacija u transformaciji zbog efekta starenja. Slitine CuAINi podložne su niskotempera-
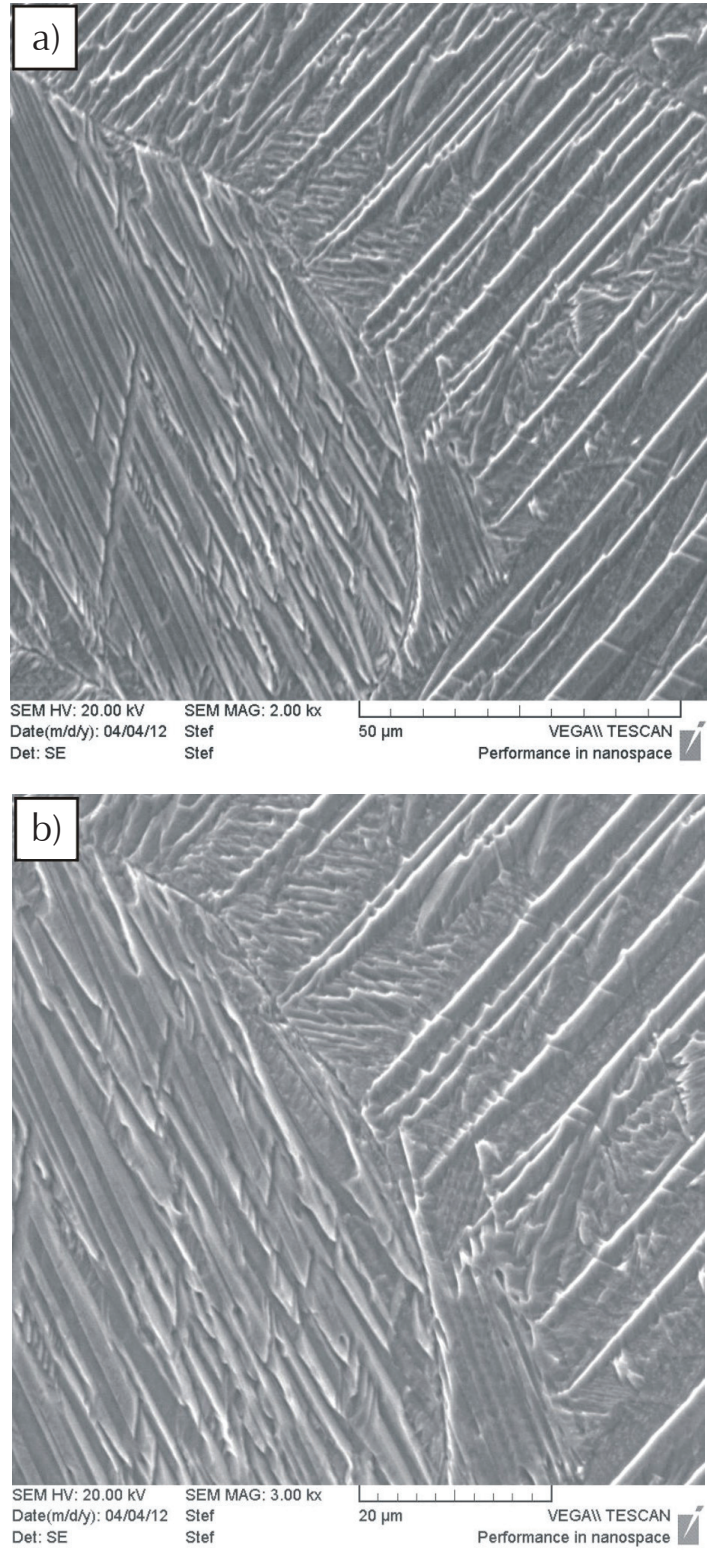

S I i k a 6 - SEM mikrografije slitine CuAINi s prisjetljivosti oblika pri različitim povećanjima ${ }^{51}$

F i g . 6 - SEM micrographs of the CUAINi shape memory alloy at different magnifications ${ }^{51}$

turnom efektu starenja koji značajno može mijenjati njihovo transformacijsko ponašanje. ${ }^{45}$ Starenje martenzita smanjuje efekt prisjetljivosti oblika i pseudoelastičnost. ${ }^{39}$

Slitine bakra s prisjetljivosti oblika mogu se vruće obrađivati na zraku, a zbog iznimne krhkosti pri niskim temperaturama neizbježan je postupak vruće deformacije. Slitine CuAlNi metastabilne su i stoga se provodi otapajuće žarenje u betafaznom području i kontrolirano hlađenje, što je potrebno za zadržavanje efekta prisjetljivosti oblika. Kaljenje u vodi često se upotrebljava kao proces kaljenja, ali se također može provoditi i hlađenje na zraku kod slitina s povećanim sadržajem aluminija. ${ }^{1,5}$

Svojstva prisjetljivosti oblika slitine CuAlNi temelje se na svojstvima binarne $\beta$-faze CuAl. Tijekom hlađenja ova faza 
prolazi eutektoidni raspad $\beta \rightarrow \alpha+\gamma_{2}$ pri $565{ }^{\circ} \mathrm{C}$. Međutim velike brzine hlađenja mogu spriječiti raspad i omogućiti martenzitnu transformaciju. 22,40

Najveći nedostatak slitine CuAINi je mali stupanj reverzibilnosti nakon deformacije ( $4 \%$ za jednosmjerni efekt prisjetljivosti oblika i oko 1,5 \% za dvosmjerni) kao posljedica intergranularnog loma pri niskom intenzitetu naprezanja. ${ }^{9,40}$

Sklonost slitine CuAINi prema intergranularnom lomu tijekom plastične deformacije povezana je s prisutnošću vrlo krhke $\gamma_{2}$-faze. Raspored, količina, veličina i oblik $\gamma_{2}$-faze dobivene u određenim uvjetima imaju značajan utjecaj na mehanička svojstva slitine CuAINi s prisjetljivosti oblika. Z. Wang et al. ${ }^{13}$ su proučavali razvoj $\gamma_{2}$-faze kontinuirano lijevane žice slitine CuAlNi s w(Cu) $=14 \%$ i $w(N i)=3,8 \%$ prije i poslije toplinske obrade. Zaključili su da se udjel $\gamma_{2}$-faze smanjuje s povećanjem temperature toplinske obrade i to $50,0 \% \gamma_{2}$-faze na $700{ }^{\circ} \mathrm{C}, 29,2 \%$ na $730{ }^{\circ} \mathrm{C}, 16,6 \%$ na $750{ }^{\circ} \mathrm{C}, 11,4 \%$ na $760{ }^{\circ} \mathrm{C}, 0,8 \%$ na $770{ }^{\circ} \mathrm{C}$ i potpuni raspad na $780{ }^{\circ} \mathrm{C}$. Također su zamijetili da s povećanjem temperature toplinske obrade dolazi do promjene u morfologiji $\gamma_{2}$-faze raspadom dendritne mikrostrukture u elipsasti oblik $(2-5 \mu \mathrm{m})$ i poligonalni oblik $(5-9 \mu \mathrm{m})$. S daljnjim povišenjem temperature $\gamma_{2}$-faza poprima sferni oblik $(2-4 \mu \mathrm{m})$. Ispitivanjem mehaničkih svojstava slitine uočili su da toplinski obrađena slitina ima bolju plastičnost, ali nisku vlačnu čvrstoću u odnosu na lijevano stanje, slika 7.

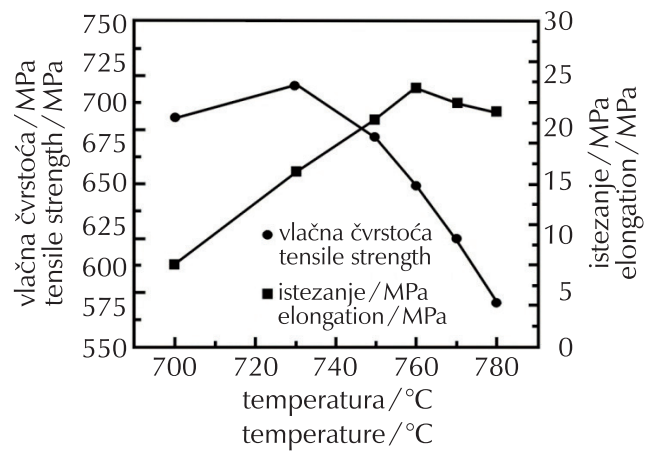

S I i k a 7 - Utjecaj temperature toplinske obrade na mehanička svojstva slitine CuAlNi ${ }^{18}$

F i g . 7 - Influence of heat treatment temperature on mechanical properties of CuAlNi alloy ${ }^{18}$

Parametar rešetke $\gamma_{2}$-faze je $0,856 \mathrm{~nm}$, što je tri puta dulje od prisutnih čestica faze NiAl u slitini CuAINi. S obzirom na to da $\gamma_{2}$-faza uzrokuje krhkost slitine, ona je i ograničavajući faktor za održavanje termoelastičnih svojstava. ${ }^{54}$

Mjerenje tvrdoće slitine CuAINi s različitim udjelom nikla (4-7\%) pokazalo je da kod slitine s udjelom nikla $4 \%$ tvrdoća s trajanjem starenja opada, dok kod slitina s udjelom nikla 5,5 i 7,0 \% tvrdoća sa starenjem raste. Maksimalna vrijednost tvrdoće postigne se nakon $10^{3}$ sekundi za slitinu s $5,5 \% \mathrm{Ni}$ odnosno nakon $10^{4}$ sekundi za slitinu sa 7,0 \% Ni. Produljenje opada nakon što su tvrdoća i čvrstoća dosegnule maksimalnu vrijednost. ${ }^{55}$

Zarubova et al. ${ }^{56}$ ispitivali su utjecaj starenja na martenzitnu transformaciju slitine CuAlNi s $w(\mathrm{Cu})=14,3 \%$ i $w(\mathrm{Ni})=$ $4,1 \%$. Promjena temperatura faznih transformacija slitine u ovisnosti o temperaturi starenja prikazana je na slici 8 .

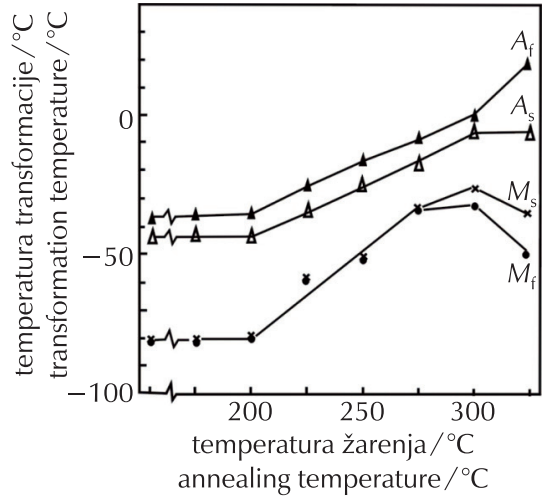

S Iika 8 - Promjena temperatura faznih transformacija slitine CuAlNi u ovisnosti o temperaturi starenja $\left(\mathrm{M}_{\mathrm{s}} i \mathrm{M}_{\mathrm{f}}\right.$ početak i završetak martenzitne transformacije, $\mathrm{A}_{\mathrm{s}} i$ $\mathrm{A}_{\mathrm{f}}$ - početak i završetak austenitne transformacije) ${ }^{56}$

F i g . 8 - Change of phase transformation temperatures of CuAlNi alloy depending on ageing temperature $\left(\mathrm{M}_{\mathrm{s}}\right.$ and $\mathrm{M}_{\mathrm{f}}-$ martensite start and finish temperature, $\mathrm{A}_{\mathrm{s}}$ and $A_{f}-$ austenite start and finish temperature) $)^{56}$

Poslije 30 min starenja na temperaturi do $200{ }^{\circ} \mathrm{C}$ nema promjene u temperaturama faznih transformacija. Pri višim temperaturama starenja zabilježen je linearni porast svih temperatura transformacije. Nakon $300{ }^{\circ} \mathrm{C}$ temperature $M_{\mathrm{s}} \mathrm{i}$ $M_{\mathrm{f}}$ se smanjuju, a temperatura $A_{\mathrm{f}}$ raste. ${ }^{56}$

Svojstvo prigušenja vibracija ili pretvaranje mehaničke energije u toplinu nije karakteristično ponašanje koje je specifično samo za slitine s prisjetljivosti oblika. Navedeno svojstvo ovisi o martenzitnoj transformaciji i međufaznoj površini između austenita i martenzita te različitim varijantama martenzita. Moguća su tri načina prigušenja u slitinama s prisjetljivosti oblika:

- mala mogućnost prigušenja - ako je slitina u početnoj austenitnoj fazi, tj. temperatura slitine je iznad temperature $M_{s^{\prime}}$ a udjel naprezanja u slitini je nizak

- na temperaturama ispod $M_{f}$ - sposobnost prigušenja raste nastajanjem većeg broja međufaznih slojeva u martenzitnoj fazi

- sposobnost prigušenja vibracija doseže svoj maksimum ako je slitina na temperaturi iznad $A_{s}$, te je prisutno dovoljno mehaničko opterećenje za nastajanje martenzita induciranog naprezanjem. ${ }^{33}$

S. H. Chang ${ }^{49}$ je istraživao svojstvo prigušenja vibracija metodom dinamičke mehaničke analize na slitini CuAINi $(w(\mathrm{Cu})$ $=13,0-14,1 \%, w(A l)=4 \%)$. Utvrđeno je da slitina $\mathrm{s}$ $14 \% \mathrm{Al}$, zahvaljujući velikoj koncentraciji pokretnih granica sraslaca u $\gamma_{1}{ }^{\prime}$-martenzitu $(2 \mathrm{H})$, zadovoljava primjenu u kojoj je potrebno svojstvo prigušenja vibracija u izotermnim uvjetima.

S obzirom na sve navedeno, slitine CuAINi mogu biti dobra zamjena za skupe slitine NiTi u nemedicinskim uvjetima proizvodnje. ${ }^{23}$

Na temelju dosada navedenih svojstava slitina s prisjetljivosti oblika cjelokupan pregled $\mathrm{i}$ usporedba osnovnih svojstava CuAINi, CuZnAl i NiTi navedeni su u tablici 2. 
Ta b I i c a 2 - Usporedba svojstava slitine CuAlNi u odnosu na NiTi i CuZnA/19

Ta ble 2 - Comparison of properties of CuAlNi with regard to NiTi and CuZnAl alloys ${ }^{19}$

\begin{tabular}{|c|c|c|c|}
\hline $\begin{array}{l}\text { Svojstva slitina } \\
\text { Properties of the alloys }\end{array}$ & CuAINi & $\mathrm{NiTi}$ & CuZnAl \\
\hline $\begin{array}{l}\text { talište } /{ }^{\circ} \mathrm{C} \\
\text { melting point } /{ }^{\circ} \mathrm{C}\end{array}$ & $1000-1050$ & 1250 & 1020 \\
\hline $\begin{array}{l}\text { granica razvlačenja / MPa } \\
\text { yield strength / MPa }\end{array}$ & 400 & 580 & $80-200$ \\
\hline $\begin{array}{l}\text { vlačna čvrstoća / MPa } \\
\text { tensile strength / MPa }\end{array}$ & $500-800$ & $800-1000$ & $500-600$ \\
\hline $\begin{array}{l}\text { duktilnost } / \% \\
\text { ductility } / \%\end{array}$ & $5-7$ & 54 & 15 \\
\hline $\begin{array}{l}\text { zamorna čvrstoća }\left(10^{6} \text { ciklusa }\right) / \mathrm{MPa} \\
\text { fatigue strength }\left(10^{6} \text { cycles }\right) / \mathrm{MPa}\end{array}$ & 350 & 350 & 270 \\
\hline $\begin{array}{l}\text { toplinski kapacitet } / \mathrm{J} \mathrm{kg}^{-1}{ }^{\circ} \mathrm{C} \\
\text { heat capacity } / \mathrm{Jgg}^{-1}{ }^{\circ} \mathrm{C}\end{array}$ & $373-574$ & $450-620$ & $390-400$ \\
\hline $\begin{array}{l}\text { toplinska provodnost na } 20^{\circ} \mathrm{C} / \mathrm{W} \mathrm{mK}^{-1} \\
\text { thermal conductivity at } 20^{\circ} \mathrm{C} / \mathrm{W} \mathrm{mK} \mathrm{mK}^{-1}\end{array}$ & $30-75$ & $8,6-18$ & $84-120$ \\
\hline $\begin{array}{l}\text { entalpija transformacije } / \mathrm{kJ} \mathrm{kg}^{-1} \\
\text { transformation enthalpy } / \mathrm{kJ} \mathrm{kg}^{-1}\end{array}$ & 9 & 28 & 7 \\
\hline $\begin{array}{l}\text { gustoća } / \mathrm{kg} \mathrm{m}^{-3} \\
\text { density } / \mathrm{kg} \mathrm{m}^{-3}\end{array}$ & $7100-7200$ & $6400-6500$ & $7540-8000$ \\
\hline $\begin{array}{l}\text { latentna toplina } / \mathrm{J} \mathrm{kg}^{-1} \\
\text { latent heat } / \mathrm{J} \mathrm{kg}^{-1}\end{array}$ & $7000-9000$ & $19000-32000$ & $7000-9000$ \\
\hline $\begin{array}{l}\text { električna otpornost } / 10^{6} \Omega \mathrm{m}^{-1} \\
\text { electrical resistivity } / 10^{6} \Omega \mathrm{m}^{-1}\end{array}$ & $0,1-0,14$ & $0,5-1,1$ & $0,07-0,12$ \\
\hline $\begin{array}{l}\text { koeficijent toplinskog širenja } / 10^{-6} \mathrm{~K}^{-1} \\
\text { thermal expansion coefficient } / 10^{-6} \mathrm{~K}^{-1}\end{array}$ & 17 & $6,6-11$ & 17 \\
\hline $\begin{array}{l}\text { maksimalno naprezanje pri oporavku/MPa } \\
\text { maximum recovery stress / MPa }\end{array}$ & $300-600$ & $500-900$ & $400-700$ \\
\hline $\begin{array}{l}\text { uobičajeno radno naprezanje / MPa } \\
\text { normal working stress / MPa }\end{array}$ & 70 & $100-130$ & 40 \\
\hline \multicolumn{4}{|l|}{$\begin{array}{l}\text { maksimalna transformacijska deformacija /\% } \\
\text { max. transformation strain } / \%\end{array}$} \\
\hline broj ciklusa / number of cycles: 1 & $5-6$ & $6-8$ & $4-6$ \\
\hline broj ciklusa / number of cycles: $<10^{2}$ & 4 & $6-8$ & 4 \\
\hline broj ciklusa / number of cycles: $<10^{5}$ & & $2-4(3)$ & \\
\hline broj ciklusa / number of cycles: $<10^{7}$ & & 0,5 & \\
\hline $\begin{array}{l}\text { normalni broj toplinskih ciklusa } \\
\text { normal number of thermal cycles }\end{array}$ & $>5 \cdot 10^{3}$ & $>10^{5}$ & $>10^{4}$ \\
\hline $\begin{array}{l}\text { Youngov modul elastičnosti / GPa } \\
\text { Young's module / GPa }\end{array}$ & $80-100$ & $28-83$ & $70-100$ \\
\hline $\begin{array}{l}\text { temperature transformacija promjene oblika } /{ }^{\circ} \mathrm{C} \\
\text { shape memory transformation temperatures } /{ }^{\circ} \mathrm{C}\end{array}$ & $-200-200$ & $-200-110$ & $-200-150$ \\
\hline $\begin{array}{l}\text { temperaturna histereza } /{ }^{\circ} \mathrm{C} \\
\text { temperature hysteresis } /{ }^{\circ} \mathrm{C}\end{array}$ & $20-40$ & $2-50$ & $5-20$ \\
\hline $\begin{array}{l}\text { maksimalni jednosmjerni efekt prisjetljivosti oblika/\% } \\
\text { max. one way memory effect/\% }\end{array}$ & 6 & 7 & 4 \\
\hline $\begin{array}{l}\text { uobičajeni dvosmjerni efekt prisjetljivosti oblika /\% } \\
\text { normal two way memory effect } / \%\end{array}$ & 1 & 3,2 & 0,8 \\
\hline $\begin{array}{l}\text { maksimalna temperatura pregrijanja } /{ }^{\circ} \mathrm{C} \\
\text { maximum overheating temperature } /{ }^{\circ} \mathrm{C}\end{array}$ & 300 & 400 & 150 \\
\hline
\end{tabular}


Ta bli c a 2 - (nastavak) Usporedba svojstava slitine CuAlNi u odnosu na NiTi i CuZnA/19

Ta ble 2 - (continued) Comparison of properties of CuAlNi with regard to NiTi and CuZnAl alloys ${ }^{19}$

\begin{tabular}{|c|c|c|c|}
\hline $\begin{array}{l}\text { Svojstva slitina } \\
\text { Properties of the alloys }\end{array}$ & CuAINi & $\mathrm{NiTi}$ & CuZnAl \\
\hline $\begin{array}{l}\text { kapacitet prigušenja vibracija /\% } \\
\text { damping capacity } / \%\end{array}$ & $10-20$ & $15-20$ & $30-85$ \\
\hline $\begin{array}{l}\text { veličina } z r n a / \mu m \\
\text { grain size } / \mu \mathrm{m}\end{array}$ & $25-100$ & $1-100$ & $50-150$ \\
\hline $\begin{array}{l}\text { taljenje, lijevanje i kontrola sastava } \\
\text { melting, casting and composition control }\end{array}$ & $\begin{array}{l}\text { prihvatljivo } \\
\text { acceptable }\end{array}$ & $\begin{array}{l}\text { teško } \\
\text { difficult }\end{array}$ & $\begin{array}{l}\text { prihvatljivo } \\
\text { acceptable }\end{array}$ \\
\hline $\begin{array}{l}\text { oblikovanje (valjanje, izvlačenje) } \\
\text { forming (rolling, extrusion) }\end{array}$ & $\begin{array}{l}\text { teško } \\
\text { difficult }\end{array}$ & $\begin{array}{l}\text { teško } \\
\text { difficult }\end{array}$ & $\begin{array}{l}\text { lako } \\
\text { easy }\end{array}$ \\
\hline $\begin{array}{l}\text { hladna deformacija } \\
\text { cold working }\end{array}$ & $\begin{array}{l}\text { vrlo teško } \\
\text { very difficult }\end{array}$ & $\begin{array}{l}\text { prihvatljivo } \\
\text { acceptable }\end{array}$ & $\begin{array}{l}\text { ograničeno } \\
\text { restricted }\end{array}$ \\
\hline $\begin{array}{l}\text { strojna obradivost } \\
\text { machinability }\end{array}$ & $\begin{array}{l}\text { dobra } \\
\text { good }\end{array}$ & $\begin{array}{l}\text { teška } \\
\text { difficult }\end{array}$ & $\begin{array}{l}\text { vrlo dobra } \\
\text { very good }\end{array}$ \\
\hline $\begin{array}{l}\text { korozijska otpornost } \\
\text { corrosion resistance }\end{array}$ & $\begin{array}{l}\text { dobra } \\
\text { good }\end{array}$ & $\begin{array}{l}\text { izvrsna } \\
\text { excellent }\end{array}$ & $\begin{array}{l}\text { prihvatljivo } \\
\text { acceptable }\end{array}$ \\
\hline $\begin{array}{l}\text { biološka kompatibilnost } \\
\text { biological compatibility }\end{array}$ & $\begin{array}{l}\text { loša } \\
\text { bad }\end{array}$ & $\begin{array}{l}\text { izvrsna } \\
\text { excellent }\end{array}$ & $\begin{array}{l}\text { loša } \\
\text { bad }\end{array}$ \\
\hline $\begin{array}{l}\text { omjer troškova } \\
\text { cost ratio }\end{array}$ & $1,5-20$ & $10-100$ & $1-10$ \\
\hline
\end{tabular}

\section{Slitine s prisjetljivosti oblika na bazi željeza}

Slitine s prisjetljivosti oblika na bazi željeza imaju najmanje istaknut efekt prisjetljivosti oblika u odnosu na ostale slitine. Međutim, zbog niže cijene u odnosu na NiTi, postoji mogućnost primjene u određenim uvjetima kao zamjena za slitinu NiTi. Kod slitina s prisjetljivosti oblika na bazi željeza može doći do martenzitne fazne transformacije fcc $\rightarrow$ bct (plošno centrirana kubična rešetka transformira se u prostorno centriranu tetragonsku strukturu) i fcc $\rightarrow$ hcp (plošno centrirana kubična rešetka transformira se u heksagonsku). Slitine koje prolaze transformaciju fcc $\rightarrow$ bct imaju zadovoljavajući efekt prisjetljivosti oblika, kao npr. FePt, FeNiCoTi i FeNiC.

Najpoznatija slitina na bazi željeza je FeMnSi, kod koje se odvija netermoelastična martenzitna transformacija fcc $\rightarrow$ hcp koja dovodi do nepotpunog jednosmjernog efekta prisjetljivosti oblika. Uz nisku cijenu, glavna prednost slitina na bazi željeza je dobra obradivost, međutim nedostatak je slaba pseudoelastičnost. Poboljšanjem korozijske otpornosti dodatkom kroma i nikla umanjuje se efekt prisjetljivosti oblika. 16,33

U slitinama na bazi željeza efekt prisjetljivosti oblika može nastati jednostavnom promjenom kristalne strukture i promjenom obujma ( $\leq 2 \%)$. Tijekom transformacije iz plošno centrirane kubične rešetke visokotemperaturne $\gamma$-faze u niskotemperaturnu $\varepsilon$-fazu heksagonske kristalne strukture dolazi do promjene u slaganju, npr. $\mathrm{ABCABC} \rightarrow \mathrm{ABABAB}$ i sl. ${ }^{57}$

Defekti u strukturi imaju važnu ulogu u martenzitnoj transformaciji $\gamma \rightarrow \varepsilon$. lako je energija defekata vrlo mala, ona predstavlja barijeru za odvijanje martenzitne transformacije kod slitina s prisjetljivosti oblika na bazi željeza. ${ }^{58}$
Poboljšanje efekta prisjetljivosti oblika u slitinama FeMnSi može se postići mikrolegiranjem ugljikom i dušikom, međutim treba biti oprezan jer je zabilježen i negativan utjecaj dušika. Utjecaj ugljika može se objasniti povećanjem granice razvlačenja zbog usporavanja kretanja dislokacijskih ravnina. Efekt prisjetljivosti oblika osjetljiv je na kristalografsku orijentaciju, stoga je uvijek superiorniji kod monokristala u odnosu na polikristalne slitine. Tekstura u slitini važna je jer može utjecati na efekt prisjetljivosti oblika, ponajprije zbog istezanja koje se pojavljuje tijekom transformacije. Istezanje tijekom transformacije ovisno je o teksturi slitine. Postizanjem poželjne teksture u osnovi $\gamma$-faze postoji mogućnost poboljšanja efekta prisjetljivosti oblika u tim slitinama.

Precipitacijsko očvršćivanje jedno je od mogućih postupaka za poboljšanje čvrstoće slitina na bazi željeza. Dobro oporavljanje oblika može se dobiti nastankom precipitata $\mathrm{NbC}$ ili VN nakon valjanja i starenja slitina FeMnSi. Pretpostavlja se da je glavni razlog za takvo poboljšanje uska povezanost precipitata $\mathrm{NbC/VN}$ i visoka gustoća slaganja pogrešaka u osnovi fcc te da do poboljšanja oporavka oblika dolazi zbog gustoće i veličine precipitata. ${ }^{58}$

\section{Proizvodnja slitina s prisjetljivosti oblika}

Tijekom komercijalne proizvodnje slitina s prisjetljivosti oblika može se javiti nekoliko problema kao npr. kontrola kemijskog sastava slitine, postizanje uvjeta hladne deformacije i toplinske ili termomehaničke obrade za postizanje efekta prisjetljivosti oblika itd. Tehnologije za proizvodnju slitina s prisjetljivosti oblika su indukcijsko taljenje, vakuumsko indukcijsko taljenje, brzo očvršćivanje (melt spinning), kontinuirano vertikalno lijevanje, taljenje elektronskim snopom, 
plazmatsko lučno taljenje. ${ }^{19,40,51,59}$ Nakon toga slijedi obrada slitina vrućom deformacijom (kovanje, valjanje) i hladnom deformacijom (vučenje i valjanje) itd. Kombinacijom ovih tehnika i toplinske obrade nastaje konačni proizvod. ${ }^{6}$

Prednosti indukcijskog taljenja su homogenost i mogućnost kontrole kemijskog sastava ingota s obzirom na to da izmjenična struja miješa talinu. $U$ tom slučaju retorta je napravljena od grafita ili $\mathrm{CaO}$. $U$ slučaju grafitne retorte kontaminacija taline kisikom i ugljikom je neizbježna. Udjel ugljika u talini ovisi o temperaturi taline. Kod slitine NiTi temperatura taline ne smije biti iznad $1450{ }^{\circ} \mathrm{C}$ jer tada grafitna retorta postaje neprimjenjiva. Udjel ugljika u talini može iznositi od 200 do 500 ppm i takve male količine ne utječu na karakteristike prisjetljivosti kod slitine $\mathrm{NiTi}^{6}{ }^{6}$

Metode brzog očvršćivanja su prihvatljive iako je postupak proizvodnje slitina s prisjetljivosti oblika vrlo zahtjevan. Brzim očvršćivanjem smatra se očvršćivanje brzinama hlađenja $10^{3} \mathrm{~K} \mathrm{~s}^{-1} \mathrm{i}$ više jer je pri visokim brzinama hlađenja, tijekom očvršćivanja i hlađenja, dostupno vrlo kratko vrijeme za odvijanje difuzijskih procesa. Stoga brzo očvršćivanje može dovesti do nastanka sitnozrnate mikrostrukture, visoke topljivosti u čvrstom stanju, manje segregacija, bolje homogenosti s malo ili bez sekundarnih faza. Zbog svega navedenog tako proizvedene slitine imaju bolju stabilnost mehaničkih svojstava na povišenim temperaturama, manje izražen rast zrna tijekom obrade, bolju otpornost na starenje i smanjenu krhkost, te može doći i do poboljšanja električnih i magnetskih svojstava te korozijske otpornosti slitine. ${ }^{40}$

Na slici 9 shematski je prikazano kontinuirano vertikalno lijevanje slitine CuAINi. Vidljivo je da slitina očvršćuje u kristalizatoru hlađenom vodom te štap određenog promjera izlazi između valjaka koji se okreću u smjeru istjecanja taline.

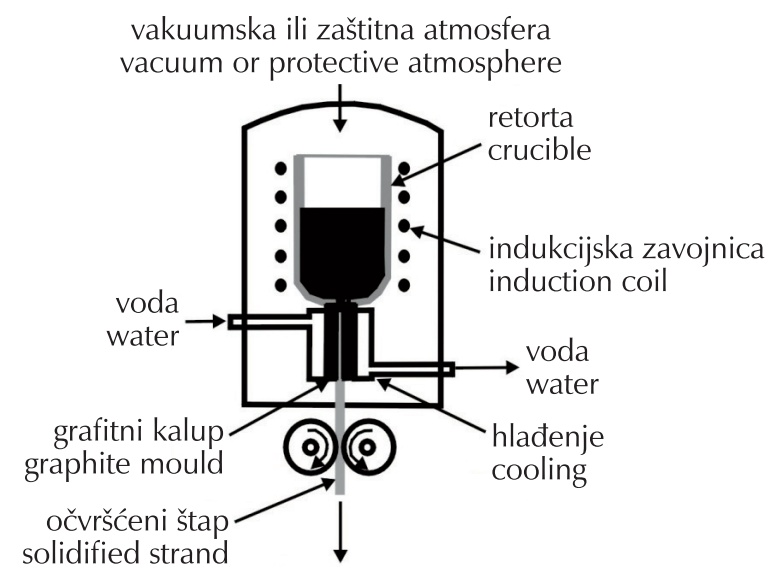

SI i k a 9 -Shematski prikaz lijevanja slitine CuAlNi tehnologijom vertikalnog lijevanja ${ }^{19}$

Fig . 9 - Schematic illustration of casting of CuAlNi alloy by vertical casting technology ${ }^{19}$

Pojam melt-spinning označava različite tehnike, kod kojih tanak mlaz taline očvršćuje u hlađenom plinu, tekućini ili na čvrstoj podlozi, za proizvodnju tankih vrpca, žice i/ili vlakana, slika 10. Najkorištenija metoda za proizvodnju brzo skrutnutih vrpci jest free jet melt spinning (također poznata kao chill block melt spinning - CBMS). Kod navedene meto- de talina kroz raşpršivač dolazi na površinu rotirajućeg valjka gdje očvršćuje. Širina vrpci može biti šira u odnosu na veličinu mlaznice, a debljina vrpce uobičajeno iznosi od 10 do $100 \mu \mathrm{m}$. Uobičajene brzine hlađenja su $10^{5}-10^{7} \mathrm{~K} \mathrm{~s}^{-1}$.

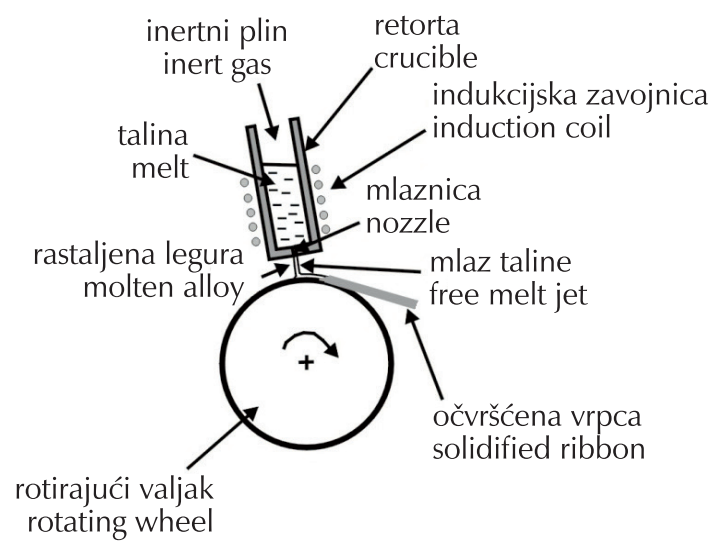

SI i k a 10 - Shematski prikaz tehnike free jet melt spinner ${ }^{40}$

Fig. 10 - Schematic presentation of free jet melt spinner technique $^{40}$

Brzine hlađenja lijevanih slitina CuAINi, CuZnAl i NiTi, koje se postižu tehnikom melt spinning, dovoljno su velike da bi se zadržala homogena $\beta$-faza neovisno o kemijskom sastavu, pri kojem bi se sporijim hlađenjem pojavile neke druge faze. Također, brzina hlađenja postignuta u slitinama s prostorno centriranom kubičnom strukturom omogućava nastanak martenzitne mikrostrukture u lijevanom stanju. Stoga, dobivene vrpce imaju efekt prisjetljivosti oblika već u lijevanom stanju. ${ }^{40}$

S porastom brzine hlađenja veličina zrna opada, a povećava se koncentracija defekata strukture što rezultira poboljšanjem mehaničkih svojstava i sniženjem transformacijskih temperatura. Koncentracija defekata strukture (slobodna mjesta, dislokacije itd.) ima vrlo velik utjecaj na temperature martenzitne transformacije. Defekti rešetke sprječavaju rast martenzita i snižavaju temperature faznih transformacija.

Također postoji mogućnost proizvodnje homogenih slitina na bazi bakra metodom mehaničkog legiranja i praškaste metalurgije. Z. Li et al. ${ }^{35}$ proizveli su slitinu CuAINiMn (maseni udjeli su bili $12 \% \mathrm{Cu}, 5 \% \mathrm{Al}$ i $2 \% \mathrm{Ni}$ ) metodama mehaničkog legiranja i praškaste metalurgije. Smjesa prahova dobiva se mljevenjem bakra, aluminija, nikla i mangana u bubnjevima s čeličnim kuglicama različitog promjera $(6,10$ i $20 \mathrm{~mm}$ ) s omjerom kuglice : prah $=15: 1$ u trajanju 1, 5, 15, 25, 35 i 45 sati pri brzini od 300 okretaja u minuti. Smjesa se zatim propuhuje argonom kako bi se izbjegla oksidacija smjese. Dobivena smjesa prahova vruće se kompaktira 120 minuta pod tlakom $30 \mathrm{MPa}$ u kalup promjera $30 \mathrm{~mm}$ pri temperaturi od $850{ }^{\circ} \mathrm{C}$ u vakuumu od $10^{-1} \mathrm{~Pa}$. Nakon toga se slitina vruće istiskuje pri $900{ }^{\circ} \mathrm{C}$. U literaturi ${ }^{36}$ je zabilježena i proizvodnja slitina s prisjetljivosti oblika CuAlNi s $w(\mathrm{Cu})=14 \%$ i $w(\mathrm{Al})=4 \%$ mehaničkim legiranjem i praškastom metalurgijom.

Međutim, zaključeno je da dobivene slitine još uvijek nemaju definirane sustavne i pogodne uvjete proizvodnje za dobivanje zadovoljavajućeg efekta prisjetljivosti oblika..$^{35,36}$ 


\section{Primjena slitina s prisjetljivosti oblika}

Slitine s prisjetljivosti oblika kao relativno novi funkcionalni materijali imaju široku mogućnost primjene. Zbog njihovih iznimnih svojstava pronalaze primjenu u mnogim industrijskim sektorima:

- strojarska industrija - cijevne spojnice, šipke za mostove, elementi za prigušenje vibracija

- elektroindustrija - antene mobilnih uređaja, osjetnici (senzori), pokretači (aktuatori), električne spojnice i prekidači, sigurnosni ventili

- medicina - kardiovaskularna kirurgija (filtri krvnih žila), ortopedska kirurgija (implantati - stentovi, vijci, fiksatori kralježnice), ortodontske naprave, okviri naočala

- moda i dekoracija itd. 2,3,5,10,11,25,26,34,58

Slitine poput nitinola dominiraju na komercijalnom tržištu (biomedicina, zrakoplovna industrija, automobilska industrija itd.), zbog njihova visokog efekta prisjetljivosti oblika, dobre pseudoelastičnosti i superiornih svojstava poput duktilnosti, povoljnih mehaničkih svojstava, korozijske otpornosti, biokompatibilnosti, biofunkcionalnosti, kao i oporavka oblika (tablica 2).

Također se javlja interes za ugrađivanje žica slitine s prisjetljivosti oblika u kompozitne matrice kako bi se promijenila frekvencija vibracije strukture ili za kontrolu oblika strukturnih elemenata. Vrlo tanke vrpce slitine NiTi s prisjetljivosti oblika mogu poslužiti kao materijal za upotrebu u proizvodnji mikrouređaja za mikrosustave poput mikrocrpki, mikrovalova, mikroomotača, mikrohvataljki, mikrozrcala, mikrokaveza itd. ${ }^{60,61}$

Slitine CuAlNi znatno su jeftinije u odnosu na slitine NiTi. Smatraju se važnim funkcionalnim materijalom za aktuatore i senzore, tzv. pametne ili inteligentne materijale. Također ove se slitine mogu upotrebljavati kao konektori za mikroelektroničke čipove.

Feromagnetične slitine s prisjetljivosti oblika mogu se upotrebljavati kao senzori ili magnetski aktuatori zbog njihova jedinstvenog svojstva - magnetski induciranih deformacija.

\section{Zaključak}

Na temelju pregleda svojstava najznačajnijih slitina s prisjetljivosti oblika može se zaključiti sljedeće:

- prisjetljivost oblika znači da materijal pod određenim uvjetima ima sposobnost vraćanja u svoj prvobitni oblik

- najpoznatija slitina s prisjetljivosti oblika je NiTi, ali je slitine na bazi bakra (CuZnAl i CuAINi) sve više zamjenjuju u nemedicinskim uvjetima primjene

- u usporedbi sa slitinom NiTi slitina CuAlZn je jednostavnija i jeftinija za proizvodnju, ima bolju električnu i toplinsku provodnost, veću duktilnost, ali lošiji efekt prisjetljivosti oblika i pseudoelastičnost

- prednosti su slitine CuAINi jednostavnija proizvodnja, niža cijena i temperature fazne transformacije do $200{ }^{\circ} \mathrm{C}$, dok je nedostatak teška obradivost u hladnom stanju, krupnozrnata mikrostruktura i sklonost lomu po granici zrna

- slitine s prisjetljivosti oblika na bazi željeza još uvijek nemaju komercijalnu primjenu. Uz nisku cijenu, ove slitine posjeduju dobru obradivost, dok pseudoelastičnost gotovo ne postoji

- tehnologije za proizvodnju slitina s prisjetljivosti oblika su indukcijsko taljenje, vakuumsko indukcijsko taljenje, brzo očvršćivanje (melt spinning), kontinuirano vertikalno lijevanje, taljenje elektronskim snopom, plazmatsko lučno taljenje, te postupci praškaste metalurgije i mehaničkog legiranja - obrada ili deformacija slitina obuhvaća vruću deformaciju (kovanje, valjanje) i hladnu deformaciju (vučenje i valjanje) - efekt prisjetljivosti oblika ključan je čimbenik za široku primjenu navedenih materijala (medicina, strojarska industrija, elektroindustrija).

\section{Popis simbola $\mathrm{i}$ kratica \\ List of symbols and abbreviations}

$A_{f} \quad$ - temperatura završetka austenitne transformacije, ${ }^{\circ} \mathrm{C}$

- austenite transformation finish temperature, ${ }^{\circ} \mathrm{C}$

$A_{s} \quad$ - temperatura početka austenitne transformacije, ${ }^{\circ} \mathrm{C}$

- austenite transformation start temperature, ${ }^{\circ} \mathrm{C}$

$N_{\mathrm{e}} / N_{\mathrm{a}}$ - omjer broja elektrona i atoma

- electron/atom number ratio

$M_{\mathrm{f}} \quad$ - temperatura završetka martenzitne transformacije, ${ }^{\circ} \mathrm{C}$

- martensite transformation finish temperature, ${ }^{\circ} \mathrm{C}$

$M_{\mathrm{s}}$ - temperatura početka martenzitne transformacije, ${ }^{\circ} \mathrm{C}$

- martensite transformation start temperature, ${ }^{\circ} \mathrm{C}$

w $\quad$ - maseni udjel, \%

- mass fraction, $\%$

x - množinski udjel, $\%$

- amount fraction, \%

B2 - kubična kristalna struktura

- cubic crystall structure

B19' - martenzitna monoklinska kristalna struktura

- martensite monoclinic crystall structure

bcc - prostorno centrirana kubična rešetka

- body-centered cubic lattice

bct - prostorno centrirana tetragonska rešetka

- body-centered tetragonal lattice

CVD - kemijsko taloženje iz parne faze

- chemical vapor deposition

$\mathrm{DO}_{24}$ - heksagonska kristalna struktura

- hexagonal crystall structure

fcc - plošno centrirana kubična rešetka

- face-centered cubic lattice

hcp - heksagonska gusto pakirana rešetka

- hexagonal close-packed lattice

SMA - slitina s prisjetljivosti oblika

- shape memory alloy

$\alpha \quad$ - primarna čvrsta otopina aluminija i nikla u bakru, struktura fCC

- primary solid solution of aluminum and nickel in copper, fcc structure

$\beta$ - visokotemperaturna neuređena faza $\mathrm{Cu}_{3} \mathrm{Al}$, bcc struktura

- high-temperature disordered phase $\mathrm{Cu}_{3} \mathrm{Al}$, bcc structure

$\beta_{1} \quad$ - austenitna faza (kristalna struktura $\mathrm{DO}_{3}$ )

- austenite phase $\left(\mathrm{DO}_{3}\right.$ crystall structure) 
$\beta_{1}^{\prime} \quad$ - martenzitna faza (kristalna struktura18R)

- martensite phase (18R crystall structure)

$\gamma \quad-$ faza $\mathrm{Cu}_{5} \mathrm{Zn}_{8}$

$-\mathrm{Cu}_{5} \mathrm{Zn}_{8}$ phase

$\gamma_{1}{ }^{\prime} \quad$ - martenzitna faza (kristalna struktura $2 \mathrm{H}$ )

- martensite phase (2H crystall structure)

$\gamma_{2}-$ faza $\mathrm{Cu}_{9} \mathrm{Al}_{4}$

- $\mathrm{Cu}_{9} \mathrm{Al}_{4}$ phase

$\varepsilon \quad$ - niskotemperaturna martenzitna faza heksagonske kristalne strukture

- low-temperature martensite phase with hexagonal crystal structure

$\chi$

- faza $(\mathrm{Cu}, \mathrm{Ni})_{2} \mathrm{TiAl}$

$-(\mathrm{Cu}, \mathrm{Ni})_{2} \mathrm{TiAl}$ phase

\section{Literatura}

\section{References}

1. D. E. Hodgson, M. H. Wu, R. J. Biermann, Shape Memory Alloys, ASM Handbook Volume 2: Properties and Selection: Nonferrous Alloys and Special-Purpose Materials, ASM Handbook Committee 1990., str. 897-902.

2. M. Gojić, Alloys with the shape memory effects, Metalurgija (in Croatien) 31 (2-3) (1992) 77-82.

3. L. G. Machado, M. A. Savi, Medical applications of shape memory alloys, Brasilian Journal of Medical and Biological Research 36 (2003) 683-691, doi: http://dx.doi.org/10.1590/ S0100-879X2003000600001.

4. K. Otsuka, X. Ren, Physical metallurgy of Ti-Ni-based shape memory alloys, Progress in Materials Science 50 (2005) 511678, doi: http://dx.doi.org/10.1016/j.pmatsci.2004.10.001.

5. D. Ćubela, Legure koje pamte svoj oblik, Mašinstvo 2 (6) (2002) 83-92.

6. K. Otsuka, C. M. Wayman, Shape memory materials, University of Cambridge, Cambridge, 1998.

7. H. Funakubo, Shape memory alloys, Gordon and Breach Science Publishers, New York, 1987.

8. D. Achitei, P. Vizureanu, N. Cimpoeşu, D. Dană, Thermo-mechanical fatigue of $\mathrm{Cu}-\mathrm{Zn}$-Al shape memory alloys, The $44^{\text {th }}$ International Conference on Mining and Metallurgy, Bor, Serbia, 2012., str. 401-404.

9. M. Čolić, R. Rudolf, D. Stamenković, I. Anžel, D. Vučević, M. Jenko, V. Lazić, G. Lojen, Relationship between microstructure, cytotoxicity and corrosion properties of a Cu-Al-Ni shape memory alloy, Acta Biomater. 6 (2010) 308-317, doi: http:// dx.doi.org/10.1016/j.actbio.2009.06.027.

10. G. Song, N. Ma, H.-N. Li, Applications of shape memory alloys in civil structures, Engineering Structures 28 (2006) 12661274, doi: http://dx.doi.org/10.1016/j.engstruct.2005.12.010.

11. J. Van Humbeeck, Nonmedical applications of shape memory alloys, Mat. Sci. Eng. A 273-275 (1999) 134-148, doi: http:// dx.doi.org/10.1016/S0921-5093(99)00293-2.

12. U. Sari, T. Kirindi, Effects of deformation on microstructure and mechanical properties of a $\mathrm{Cu}-\mathrm{Al}-\mathrm{Ni}$ shape memory alloy, Mater. Charact. 59 (2008) 920-929, doi: http://dx.doi. org/10.1016/j.matchar.2007.07.017.

13. Z. Wang, X. F. Liu, J. X. Xie, Effects of solidification parameters on microstructure and mechanical properties of continuous columnar-grained Cu-Al-Ni alloy, Prog. Nat. Sci. 21 (2011) 368-374, doi: http://dx.doi.org/10.1016/S10020071(12)60071-9.
14. C. E. Sobrero, P. La Roca, A. Roatta, R. E. Bolmaro, J. Malarría, Shape memory properties of highly textured Cu-Al-Ni-(Ti) alloys, Mat. Sci. Eng. A 536 (2012) 207-215, doi: http://dx.doi. org/10.1016/S1002-0071(12)60071-9.

15. W. H. Zou, H. Y. Peng, R. Wang, J. Gui, D. Z. Yang, Heating effects on fine structure of Cu-Al-Ni-Mn-Ti shape memory alloy, Acta Metall. Mater. 43 (8) (1995) 3009-3016, doi: http:// dx.doi.org/10.1016/0956-7151(95)00016-O.

16. J. Van Humbeeck, L. Delaey: A comparative review of the (Potential) Shape Memory Alloys, ESOMAT 1989 - Ist European Symposium on Martensitic Transformations in Science and Technology, Bochum, Germany, 1989., str. 15-26.

17. C. Segui, E. Cesari, Effect of Mn on Ageing of Cu-Al-Ni-Mn-B Alloys, J. Phys. IV France 5 (1995) 187-191, doi: http://dx.doi. org/10.1051/jp4:1995229.

18. Z. Wang, X. F. Liu, J. X. Xie, Effect of $\gamma_{2}$ phase evaluation on mechanical properties of continuous columnar-grained $\mathrm{Cu}-\mathrm{Al}-\mathrm{Ni}$ alloy, Mat. Sci. Eng. A 532 (2012) 536-542, doi: http://dx.doi. org/10.1016/j.msea.2011.11.019.

19. M. Gojić, S. Kožuh, B. Kosec, I. Anžel, Properties and applications of shape memory alloys, IX Naučno-stručni simpozij "Metalni i nemetalni materijali“, Zenica, 2012., str. 13-23.

20. A. Biesiekierski, J. Wang, M. A.-H. Gepreel, C. Wen, A new look at biomedical Ti-based shape memory alloys, Acta Biomater. 8 (2012) 1661-1669, doi: http://dx.doi.org/10.1016/j. actbio.2012.01.018.

21. L. Sun, W. M. Huang, Z. Ding, Y. Zhao, C. C. Wang, H. Purnawali, C. Tang, Stimulus-responsive shape memory materials: A review, Materials and Design 33 (2012) 577-640, doi: http:// dx.doi.org/10.1016/j.matdes.2011.04.065.

22. A. C. Kneissl, E. Unterweger, M. Bruncko, G. Lojen, K. Mehrabi, H. Scherngell, Microstructure and Properties of NiTi and CuAINi Shape Memory Alloys, Metalurgija 14 (2008) 89-100. URL: $\quad$ http://www.metalurgija.org.rs/mjom/vol14/No\%20 2/2KNEISSL.pdf (2. 1. 2013.).

23. A. Creuziger, W. C. Crone, Initial transformation around a notch tip in CuAINi: Experiment and modeling, Acta Mater. 56 (2008) 518-526, doi: http://dx.doi.org/10.1016/j.actamat.2007.09.043

24. N. Figueira, T. M. Silva, M. J. Carmezim, J. C. S. Fernandes, Corrosion behaviour of $\mathrm{NiTi}$ alloy, Electrochim. Acta $\mathbf{5 4}$ (2009) 921-926, doi: http://dx.doi.org/10.1016/j.electacta.2008.08.001.

25. W. M. Huang, C. L. Song, Y. Q. Fu, C. C. Wang, Y. Zhao, H. Purnawali, H. B. Lu, C. Tang, Z. Ding, J. L. Zhang, Shaping tissue with shape memory materials, Adv. Drug Deliver. Rev. 65 (2013) 515-535, doi: http://dx.doi.org/10.1016/j. addr.2012.06.004.

26. G. Song, N. Ma, H.-N. Li, Applications of shape memory alloys in civil structures, Eng. Struct. 28 (2006) 1266-1274, doi: http://dx.doi.org/10.1016/j.engstruct.2005.12.010.

27. M. L. Castro, R. Romero, Transformation during continuous cooling of a $\beta$-Cu-22.72Al-3.55Be (at. \%) alloy, Scripta Mater. 42 (2000) 157-161, doi: http://dx.doi.org/10.1016/S13596462(99)00330-9.

28. S. Montecinos, A. Cuniberti, A. Sepúlveda, Grain size and pseudoelastic behaviour of a Cu-Al-Be alloy, Mater. Charact. 59 (2008) 117-123, doi: http://dx.doi.org/10.1016/j. matchar.2006.11.009.

29. Z. G. Wei, H. Y. Peng, D. Z. Yang, C. Y. Chung, J. K. L. Lai, Reverse transformations in CuAINiMnTi alloy at elevated temperatures, Acta Mater. 44 (3) (1996) 1189-1199, doi: http:// dx.doi.org/10.1016/1359-6454(95)00233-2.

30. C. Segui, E. Cesari, Effect of Mn on Ageing of Cu-Al-Ni-Mn-B Alloys, J. Phys. IV 5 (1995) 187-191, doi: http://dx.doi. org/10.1051/jp4:1995229. 
31. N. M. Lohan, B. Pricop, L.-G. Bujoreanu, N. Cimpoeşu, Heating rate effects on reverse martensitic transformation in a Cu-ZnAl shape memory alloy, Int. J. of Mater. Res. 102 (11) (2011) 1345-1351, doi: http://dx.doi.org/10.3139/146.110595.

32. V. Asanović, K. Delijić, N. Jauković, A study of transformations of $\beta$-phase in $\mathrm{Cu}-\mathrm{Zn}$-Al shape memory alloys, Scripta Mater. 58 (2008) 599-601, doi: http://dx.doi.org/10.1016/j.scriptamat.2007.11.033.

33. E. Patoor, D. C. Lagoudas, P. B. Entchev, L. C. Brinson, X. Gao, Shape memory alloys, Part I: General properties and modeling of single crystals, Mech. Mater. 38 (2006) 391-429, doi: http://dx.doi.org/10.1016/j.mechmat.2005.05.027.

34. W. M. Huang, Z. Ding, C. C. Wang, J. Wei, Y. Zhao, H. Purnawali, Shape memory materials, Mater. Today 13 (2010) 54-61, doi: http://dx.doi.org/10.1016/S1369-7021(10)70128-0.

35. Z. Li, Z. Y. Pan, N. Tang, Y. B. Jiang, N. Liu, M. Fang, F. Zheng, $\mathrm{Cu}-\mathrm{Al}-\mathrm{Ni}-\mathrm{Mn}$ shape memory alloy processed by mechanical alloying and powder metallurgy, Mat. Sci. Eng. A 417 (2006) 225-229, doi: http://dx.doi.org/10.1016/j.msea.2005.10.051.

36. S. M. Tang, C. Y. Chung, W.G. Liu, Preparation of Cu-Al-Ni Shape Memory Alloys by Mechanical Alloying and Powder Metallurgy Method, J. Mater. Process. Tech. 63 (1997) 307312, doi: http://dx.doi.org/10.1016/S0924-0136(96)02641-6.

37. C. E. Sobrero, P. La Roca, A. Roatta, R. E. Bolmaro, J. Malarría, Shape memory properties of highly textured $\mathrm{Cu}-\mathrm{Al}-\mathrm{Ni}-(\mathrm{Ti})$ alloys, Mat. Sci. Eng. A 536 (2012) 207-215, doi: http://dx.doi. org/10.1016/j.msea.2011.12.104.

38. Z. Xiao, Z. Li, M. Fang, S. Xiong, X. Sheng, M. Zhou, Effect of processing of mechanical alloying and powder metallurgy on microstructure and properties of Cu-Al-Ni-Mn alloy, Mat. Sci. Eng. A 488 (2008) 266-272, doi: http://dx.doi.org/10.1016/j. msea.2007.11.037.

39. W. H. Zou, H. Y. Peng, R.Wang, J. Gui, D. Z. Yang, Heating effects on fine structure of a Cu-Al-Ni-Mn-Ti shape memory alloy, Acta Metall. Mater. 43 (8) (1995) 3009-3016, doi: http:// dx.doi.org/10.1016/0956-7151(95)00016-O.

40. G. Lojen, I. Anžel, A. Kneissl, A. Križman, E. Unterweger, B. Kosec, M. Bizjak, Microstructure of rapidly solidified Cu-Al$\mathrm{Ni}$ shape memory alloy ribbons, J. Mater. Process. Tech. 162163 (2005) 220-229, doi: http://dx.doi.org/10.1016/j.jmatprotec.2005.02.196.

41. R. Gastien, C. E. Corbellani, M. Sade, F. C. Lovey, Thermodynamical aspects of martensitic transformations in CuAINi single crystals, Scripta Mater. 50 (2004) 1103-1107, doi: http:// dx.doi.org/10.1016/j.scriptamat.2004.01.032.

42. R. Gastien, C. E. Corbellani, P. B. Bozzano, M. L. Sade, F. C. Lovey, Low temperature isothermal ageing in shape memory CuAINi single crystals, J. Alloys Compd. 495 (2010) 428-431, doi: http://dx.doi.org/10.1016/j.jallcom.2009.10.100.

43. G. Covarel, V. Pelosin, A. Rivière, Influence of annealings on CuAINi martensite studied by internal friction, Scripta Mater. 46 (2002) 319-324, doi: http://dx.doi.org/10.1016/S13596462(01)01248-9.

44. U. Sari, I. Aksoy, Electron microscopy study of $2 \mathrm{H}$ and $18 \mathrm{R}$ martensites in $\mathrm{Cu}-11.92 \mathrm{wt} \% \mathrm{Al}-3.78 \mathrm{wt} \% \mathrm{Ni}$ shape memory alloy, J. Alloys Compd. 417 (2006) 138-142, doi: http://dx. doi.org/10.1016/j.jallcom.2005.09.049.

45. A. Aydogdu, Y. Aydogdu, O. Adigüzel, Improvement of Hardness and Microstructure by Ageing in Shape Memory CuAlNi Alloys, J. Phys. IV 7 (1997) 311-316, doi: http://dx.doi. org/10.1051/jp4:1997549.
46. O. Adiguzel, Smart materials and influence of atom sizes on martensite microstructures in copper-based shape memory alloys, J. Mater. Process. Tech. 185 (2007) 120-124, doi: http:// dx.doi.org/10.1016/j.jmatprotec.2006.03.111.

47. S. Vedantam, R. Abeyaratne, A Helmholtz free-energy function for a Cu-Al-Ni shape memory alloy, Int. J. Nonlinear Mech. 40 (2005) 177-193, doi: http://dx.doi.org/10.1016/j.ijnonlinmec.2004.05.005.

48. D. Liu, H. Hashimoto, Electron microscopy study of martensite in Cu-11.2wt.\% Al-3wt.\%Ni, J. Mater. Sci. 32 (1997) 16571663, doi: http://dx.doi.org/10.1023/A:1018507512870.

49. S. H. Chang, Influence of chemical composition on the damping characteristics of $\mathrm{Cu}-\mathrm{Al}-\mathrm{Ni}$ shape memory alloys, Mater. Chem. Phys. 125 (2011) 358-363, doi: http://dx.doi. org/10.1016/j.matchemphys.2010.09.077.

50. S. W. Husain, P. C. Clapp, The effect of ageing on the fracture behavior of Cu-Al-Ni $\beta$ phase alloys, Metall. Trans. 19A (1988) 1761-1766, doi: http://dx.doi.org/10.1007/BF02645144.

51. M. Gojić, S. Kožuh, I. Anžel, G. Lojen, I. Ivanić, B. Kosec, Microstructural and phase analysis of CuAINi shape-memory alloy after continuous casting, Mater. Technol. 47 (2) (2013) 149-152.

52. H. Kato, Y. Yasuda, K. Sasaki, Thermodynamic assessment of the stabilization effect in deformed shape memory alloy martensite, Acta Mater. 59 (2011) 3955-3964, doi: http://dx.doi. org/10.1016/j.actamat.2011.03.021.

53. S. Nevin Balo, N. Sel, Effects of thermal aging on transformation temperatures and some physical parameters of $\mathrm{Cu}$ 13.5wt.\%Al-4wt.\%Ni shape memory alloy, Thermochim. Acta 536 (2012) 1-5, doi: http://dx.doi.org/10.1016/j. tca.2012.02.007.

54. J. L. L. Gama, C. C. Dantas, N. F. Quadros, R. A. S. Ferreira, Y. P. Yadava, Microstructure - Mechanical Property Relationship to Copper Alloys with Shape Memory during Thermomechanical Treatments, Metall. Mater. Trans. A 37 (2006) 77-87.

55. Y.-R. Cho, Y.-H. Kim, T. D. Lee, Precipitation hardening and recrystallisation in $\mathrm{Cu}-4 \%$ to $7 \% \mathrm{Ni}-3 \% \mathrm{Al}$ alloys, J. Mater. Sci. 26 (1991) 2879-2886, doi: http://dx.doi.org/10.1007/ BF01124816.

56. N. Zárubová, A. Gemperle, V. Novák, Initial stages of $\gamma_{2}$ precipitation in an aged Cu-Al-Ni shape memory alloy, Mat. Sci. Eng. A 222 (1997) 166-174, doi: http://dx.doi.org/10.1016/ S0921-5093(96)10520-7.

57. P. Donner, Microstructure and phase-transformation in meltspun shape memory alloys, J. Phys. IV 1 (1991) 335-360, doi: http://dx.doi.org/10.1051/jp4:1991453.

58. T. W. Duerig, J. Albrecht, G. H. Gessinger, A Shape Memory Alloy for High-Temperature Applications, J. Met. 12 (1982) 14-20, doi: http://dx.doi.org/10.1007/BF03338156.

59. I. Ivanić, M. Gojić, S. Kožuh, M. Rimac, O. Beganović, K. Begović, D. Čubela, Razvoj Cu slitina s prisjetljivosti oblika, Conference Proceedings of Techno-Educa 2012., Zenica, BiH, 2012., str. 82-87.

60. R. Zarnetta, S. Kneip, Ch. Somsen, A. Ludwig, High-throughput characterization of mechanical properties of Ti-Ni-Cu shape memory thin films at elevated temperature, Mat. Sci. Eng. A 528 (2011) 6552-6557, doi: http://dx.doi.org/10.1016/j. msea.2011.05.006.

61. T. Shahrabi, S. Sanjabi, E. Saebnoori, Z. H. Barber, Extremely high pitting resistance of NiTi shape memory alloy thin film in simulated body fluids, Mater. Lett. 62 (2008) 2791-2794, doi: http://dx.doi.org/10.1016/j.matlet.2008.01.052. 


\title{
EXTENDED ABSTRACT
}

Shape Memory Alloys (Part II): Classification, Production and Application

\author{
I. Ivanić, ${ }^{*}$ M. Gojić, and S. Kožuh
}

Shape memory alloys (SMAs) have been extensively investigated because of their unique shape memory behaviour, i.e. their ability to recover their original shape they had before deformation. Shape memory effect is related to the thermoelastic martensitic transformation. Austenite to martensite phase transformation can be obtained by mechanical (loading) and thermal methods (heating and cooling). Depending on thermomechanical conditions, SMAs demonstrate several thermomechanical phenomena, such as pseudoelasticity, superelasticity, shape memory effect (one-way and two-way) and rubber-like behaviour.

Numerous alloys show shape memory effect (NiTi-based alloys, Cu-based alloys, Fe-based alloys etc.). Nitinol (NiTi) is the most popular and the most commonly used SMA due to its superior thermomechanical and thermoelectrical properties. NiTi alloys have greater shape memory strain and excellent corrosion resistance compared to $\mathrm{Cu}$ - based alloys. However, they are very costly. On the other hand, copper-based alloys (CuZn and CuAl based alloys) are much less expensive, easier to manufacture and have a wider range of potential transformation temperatures. The characteristic transformation temperatures of martensitic transformation of CuAINi alloys can lie between -200 and $200{ }^{\circ} \mathrm{C}$, and these temperatures depend on $\mathrm{Al}$ and $\mathrm{Ni}$ content. Among the $\mathrm{Cu}-$ based SMAs, the most frequently applied are CuZnAl and CuAINi alloys. Although CuZnAl alloys with better mechanical properties are the most popular among the Cu-based SMAs, they lack sufficient thermal stability, while CuAINi shape memory alloys, in spite of their better thermal stability, have found only limited applications due to insufficient formability owing to the brittle $\gamma_{2}$ precipitates. The most important disadvantage of polycrystalline CuAINi alloys is a small reversible deformation (one-way shape memory effect: up to $4 \%$; two-way shape memory effect: only approximately $1.5 \%)$ due to intergranular breakdown at low stress levels.

The technologies for production of shape memory alloys are induction melting, vacuum melting, vacuum arc melting, following hot and cold working (forging, rolling, wire drawing). In addition, rapid solidification methods, like melt spinning and continuous casting have been developed. These methods are characterized by high cooling rates. High cooling rates allow very short time for diffusion processes and may lead to extremely fine microstructure, better homogeneity etc.

SMAs have found applications in many areas due to their thermomechanical and thermoelectrical properties (biomedical applications, engineering industry, electrical industry).

In this paper, a review of shape memory alloys, properties and applications of mentioned materials is presented. 
